\title{
Exploring Undergraduates' Perception on Assessments and Feedbacks at Selected Nigerian and South African Rural Universities
}

\author{
Chinaza Uleanya \\ Department of Educational Management and Leadership, University of Johannesburg, South Africa
}

Received November 9, 2020; Revised December 14, 2020; Accepted January 20, 2021

\section{Cite This Paper in the following Citation Styles}

(a): [1] Chinaza Uleanya, "Exploring Undergraduates' Perception on Assessments and Feedbacks at Selected Nigerian and South African Rural Universities," Universal Journal of Educational Research, Vol. 9, No. 4, pp. 836 - 843, 2021 DOI: 10.13189/ujer.2021.090417.

(b): Chinaza Uleanya (2021). Exploring Undergraduates' Perception on Assessments and Feedbacks at Selected Nigerian and South African Rural Universities. Universal Journal of Educational Research, 9(4), 836 - 843. DOI: 10.13189/ujer.2021.090417.

Copyright $\mathrm{O} 2021$ by authors, all rights reserved. Authors agree that this article remains permanently open access under the terms of the Creative Commons Attribution License 4.0 International License

\begin{abstract}
The role of lecturers in tertiary institutions of learning is crucial. Some of the crucial roles of lecturers include assessment and feedbacks provided to students. These are considered as contributory factors to improving or hampering the learning abilities of students. Hence, this study explored the effects of assessment and feedback on the learning abilities of students in selected rural based universities in Nigeria and South Africa. Quantitative research method was employed for the study. Thus, data were collected from respondents through the use of questionnaires which were administered to nine hundred and thirty-four (934) randomly selected third-year undergraduate students from two Nigerian and South African rural based universities. The collected data were analysed through the use of descriptive statistics. The results revealed that lack of innovation, large classes and poor internet amongst others are factors affecting the form of assessments and feedback given to students. Also, poor assessment and feedbacks contribute in hampering the learning abilities of students. The study therefore recommends that more lecturers should be employed, empowered through the provision of necessary facilities as well as all-encompassing periodic on the job trainings and workshops. These trainings and workshops are to be designed in such a manner that lecturers will be motivated and taught various ways on how to promote good lecturer-student relationship, improvise in creating using different assessment and feedback strategies, acquire and utilize best practices across the globe on assessing and
\end{abstract}

giving feedback to large classes.

Keywords Assessment, Feedbacks, Nigeria, Rural Based Universities, South Africa

\section{Introduction}

Assessment is an area of challenge in the African learning context [1]. Ref. [1] further opines that the way students are assessed, monitored and evaluated in African institutions differs from what is obtainable in other tertiary institutions abroad. Ref. [1] states that the prerequisite to be followed when assessing students is not usually followed in some African tertiary institutions of learning. Hence, the rate at which feedback is given to students is hampered since there seems to be deficiency in the area of assessment. Meanwhile, a review of the work of Boud [2] suggests that the level of monitoring given to students in African tertiary institutions is questionable. Ref. [2] opines that better monitoring is to be put in place for better results to be experienced. Thus, $[1,2]$ concur that learning challenges amongst students in tertiary institutions in Africa are constituted by the kind of assessment given to them.

Also, in the area of assessment various forms of both the lecturers and students are lagging in different ways. Assessment of students is basically meant to be a source of feedback from the lecturers to the students. 
Unfortunately, South African universities are not different from other universities across the continent. Students get involved in different forms of malpractices such as plagiarism, taking micro-chips in for examinations, among others $[3,4]$ in order to attain good academic grades, thereby making it difficult for the lecturers to know their academic level. According to Samford, Shacklock, Connors, Galtung [5], lecturers on the other hand, tend to aid and abet this criminal offence by intentionally allowing leakages and this increases the rate of learning challenges amidst the students. In South African universities, assessment has been organized in a manner that seems to be known by both the lecturers and students. For instance, the students are aware that they will be assessed on an individual basis and group basis. At the level of group base assessment, some students tend to abscond, leaving it into the hands of few who try as much as they can to ensure maximum production, yet sometimes they all end up scoring the same grades. This will definitely affect those students who chose to abscond. Thus, all tasks given to students at any level are to be carried out under the supervision of lecturers Daniels, McBride [6]. However, in Nigerian higher institutions of learning, this seems not to be carried out properly. According to Anzene [7], students are majorly interested in getting certificates, rather than the knowledge which should be desired and required. This is based on the demand and expectation of the society. In most cases when people go for job interviews, they are first asked to tender their certificates not to prove their skills. Thus, in Nigeria, the emphasis is on acquisition of certificates. Students are sometimes assessed wrongly due to population and focus on meeting the target set by the administrative body of the institution. Sometimes, multiple choice question style is adopted in place of essay form. Similarly, theory is used in some instances in place of practical. In other situations, scripts are transferred to students to assess their fellow students. In such situations, it becomes difficult for the lecturer to give a proper feedback to the students. Meanwhile, Anzene [7] states that assessment of students must be appropriately carried out. This implies that the way and manner assessments are conducted for students are crucial and paramount to their success.

Additionally, communication theory is adopted for this study as teaching and learning exercise is considered a two-way phenomenon which involves two different parties/entities as communication, especially in the recent era where learner-centred teaching method is highly encouraged. Communication theory is otherwise referred to as an arm of knowledge which deals with methods and principles via which message(s) (information) is passed across from one person to another. In the class room setting, it implies the aspect of knowledge through which instruction / information is passed across from the lecturer to the student. In the same vein, students are expected to respond to lecturers. Various communication theories can be adopted in teaching and learning environment, however, they are all dependent on the teaching approach / method adopted by the teacher. For instance, while Aristotle Model of Communication may be acceptable in a teaching environment where teacher-centered method has been adopted as the teacher is considered as a sage and provider of all information, it may be considered inappropriate in a different learning situation. Conversely, Berlo's Communication Model which takes into cognizance the emotional aspect(s) of the information / instruction to be passed may be unsuitable in some teaching environment as emphasis is also on the speaker, in the context of this study, the lecturer. In this study, the researcher finds the communication model proposed by Wilber Schramm in 1954 as the most appropriate. The model is described as Schramm's Communication Model. It mainly focuses on three entities known as: "The Sender, The Message and The Receiver". According to Schramm's Communication Model, communication is a two-way phenomenon which does not begin and end with only one entity, rather, it is only considered effective when there is / are continuous back and forth message(s) from one entity to another. The model is represented as:

\section{Sender \\ $\mathbf{M} \downarrow \uparrow \mathbf{M}$ \\ Receiver}

Source: Schramm's Communication Model

The model can be rewritten as:

$$
\begin{gathered}
\mathbf{S} \\
\mathbf{M} \downarrow \\
\\
\mathbf{R}
\end{gathered}
$$

Source: Adapted from Schramm's Communication Model by the researcher

"S" remains the symbol of Sender, "M" represents message, while "R" stands for receiver. The arrows pointing up and down towards " $\mathrm{S}$ and $\mathrm{R}$ " respectively indicate the movement of the message(s), that is from sender to receiver, vis-à-vis, from receiver to sender. In the context of this study, "S" which stands for "sender" will represent lecturers, while " $R$ " which represents "receiver" will be used to mean student. Hence, the model as adopted in this study implies the representation below:

$$
\begin{gathered}
\mathbf{L} \\
\mathbf{M} \downarrow \uparrow \mathbf{M} \\
\mathbf{S}
\end{gathered}
$$

Source: Adapted from Schramm's Communication Model by the researcher

In the university system, this will mean:

$$
\begin{gathered}
\text { Lecturers } \\
\mathbf{M} \downarrow \uparrow \mathbf{M} \\
\text { Students }
\end{gathered}
$$

Source: Adapted from Schramm's Communication Model by the researcher 
This implies that lecturers pass information to students, the students in turn pass information to the lecturers, who do the same again. The communication channel is expected to continue. Suffice to state that assessments and feedbacks are important in teaching and learning environments. For instance, lecturers lecture (teach), and assess their students. They are expected to give feedback to every assessment and possibly wait for the students to comment based on the feedback if the need arises. Hence, the reason for this study which aims at exploring the effects of assessments and feedbacks to undergraduates using selected rural based Nigerian and South African universities, by attempting to proffer answer to the questions: what are the perceptions of students on the assessments and feedbacks given to them by lecturers? What effects do the forms of assessments and feedbacks from lecturers have on the learning abilities and academic performances of students in the selected rural based South African and Nigerian universities?

\section{Methodology}

\section{Research Design}

Quantitative method was adopted for data collection. This was to ensure the collection of quantitative (huge) data in order to enhance generalization of findings. According to $[8,9]$, quantitative method can be adopted in research studies to enhance generalization of findings due to the number of respondents involved.

\section{Population and Sample}

The population comprises rural undergraduate university students and lecturers in selected universities in South Africa and Nigeria. The sample of the study consists of nine hundred and thirty-four (934) randomly selected third year undergraduate students from two Nigerian and South African rural based universities. Third-year students were adopted for the study due to the number of years and experiences they have had in the selected rural universities. Moreover, it is expected that third-year students would have had experiences in assessment and feedbacks from lecturers. The universities were purposively selected based on their locations, size, source of funding, course / programmes, amongst other characteristics that are similar in the two institutions. Meanwhile, the students were randomly selected in order to give all interested third-year students in the selected rural based universities opportunities to participate in the study and to avoid all forms of bias in data collection. The respondents comprised 490 and 444 undergraduates from the selected South African and Nigerian rural based universities respectively.

\section{Instrument, Administration and Analysis}

Self-designed questionnaire was employed for data collection. The questionnaires were used to gather quantitative data from the student respondents. The study aimed at exploring assessments and feedbacks to undergraduates at selected rural based Nigerian and South African universities. A 3-point Likert scale self-designed questionnaire was used. The scale points are as follow:

\begin{tabular}{|c|c|c|}
\hline Yes & Unsure & No \\
\hline 3 Points & 2 Points & 1 Point \\
\hline
\end{tabular}

The questionnaire consisted of two sections. The first section described as 'Section A' was targeted at collecting data on the demography of the respondents. Meanwhile the second section which was tagged: 'Section B' collected information on the opinions of student respondents based on their experiences on assessment and feedbacks from lecturers at their different selected universities. The scores obtained by the respondents on questionnaire items were analysed using simple percentage and frequency counts. The data obtained were analysed statistically using frequency count and simple percentage.

\section{Results and Discussions}

The demographic data of the respondents across the selected rural universities in South Africa and Nigeria are as presented in Table 1 below:

Table 1. The demographic data of undergraduate university students in the selected rural universities in South Africa and Nigeria

\begin{tabular}{|c|c|c|c|c|}
\hline \multirow[t]{2}{*}{ DEMOGRAPHICS } & \multicolumn{2}{|c|}{ South Africa } & \multicolumn{2}{|c|}{ Nigeria } \\
\hline & $\begin{array}{l}\text { Frequency } \\
(\mathrm{N}=490)\end{array}$ & $\begin{array}{c}\text { Percent } \\
(\%)\end{array}$ & $\begin{array}{l}\text { Frequency } \\
(\mathrm{N}=444)\end{array}$ & $\begin{array}{c}\text { Percent } \\
(\%)\end{array}$ \\
\hline \multicolumn{5}{|l|}{ GENDER } \\
\hline Male & 241 & 49.2 & 219 & 49.3 \\
\hline Female & 249 & 50.8 & 225 & 50.7 \\
\hline \multicolumn{5}{|l|}{ AGE } \\
\hline $18-29$ & 469 & 95.7 & 411 & 92.6 \\
\hline $30-39$ & 21 & 4.3 & 29 & 6.5 \\
\hline 40-Above & 00 & 00 & 4 & 0.90 \\
\hline \multicolumn{5}{|l|}{ ETHNICITY } \\
\hline Black & 478 & 97.6 & 444 & 100.0 \\
\hline Indian & 12 & 2.4 & 00 & 00 \\
\hline \multicolumn{5}{|l|}{$\begin{array}{l}\text { MARITAL } \\
\text { STATUS }\end{array}$} \\
\hline Single & 477 & 97.3 & 401 & 90.3 \\
\hline Married & 12 & 2.4 & 43 & 9.7 \\
\hline Divorced & 1 & 0.20 & 0 & 0.00 \\
\hline \multicolumn{5}{|l|}{ FACULTY } \\
\hline $\begin{array}{l}\text { Agriculture and } \\
\text { Science }\end{array}$ & 139 & 28.4 & 68 & 15.3 \\
\hline Arts & 158 & 32.2 & 124 & 28.0 \\
\hline Social Science & 75 & 15.3 & 112 & 25.2 \\
\hline Education & 118 & 24.1 & 140 & 31.5 \\
\hline
\end{tabular}


COMPARISON OF DEMOGRAPHIC DATA OF RESPONDENTS IN SELECTED SOUTH AFRICAN AND NIGERIAN RURAL BASED UNIVERSITIES

Table 1 shows the demographic profile of students who responded to the administered questionnaires. Collected data on the demographics of respondents from the selected South African and Nigerian rural universities are as presented. Variables such as gender, ethnicity, marital status and faculty of respondents constitute the demographics of the of the respondents. Sequel to the analysis on the demographics of respondents, the findings show that majority of the students who responded to the questionnaires were blacks, singles and mostly between the ages of 18-29. The analysis shows that 241 out of 490 respondents from the selected South African rural university were males, while 249 were females. Meanwhile, 219 out of 444 of the students from the selected Nigerian rural university were males and 225 were females. With regards to the age of the respondents, 469 out of the 490 respondents from the selected South African rural university were between the ages of 18-29 years, 21 respondents were between the age of 30-39 and none was 40 and above. From the selected rural based Nigerian university, the number of respondents whose age was between 18-29 was 411,29 were between ages 30-39, while 4 were between 40 and above. This shows that majority of the respondents from both selected institutions across the two countries were between ages 18-29. Additionally, while 478 respondents from the selected South African rural based university were blacks, 12 were Indians, meanwhile, all 444 respondents from the selected rural based Nigerian university were blacks. This shows that the respondents of the study from across the two selected rural universities in both South Africa and Nigeria were majorly blacks. Considering the marital status of the respondents of the study, majority were singles, followed by married and then divorced. For instance, 477 of the South African respondents were singles, 12 were married and 1 was divorced. Meanwhile, 401 of the Nigerian respondents were single, 43 were married and none was divorced. Four different faculties were represented. For instance, 139 respondents from the selected South African university were from the Faculty of Agriculture and Science, 158 were from the Faculty of Arts, 75 were from the Faculty of Social Science, while 118 were from the Faculty of Education. Meanwhile, 68 respondents from the selected Nigerian university were from the Faculty of Agriculture and Science, 124 were from the Faculty of Arts, 112 were from the Faculty of Social Science, while 140 were from the Faculty of Education. The researcher selected similar faculties in order to ensure uniformity.

Table 2 shows respondents' responses to their perception on the level of assessment given by lecturers. The findings show that $19.0 \%$ of the South African student respondents disagreed that they were well assessed by their lecturers every semester, $31.4 \%$ were unsure, while $49.6 \%$ agreed. From the Nigerian students, $12.4 \%$ disagreed that they were well assessed by lecturers every semester, while $29.3 \%$ were unsure, and $58.3 \%$ agreed. This finding shows that majority of the students from the two selected rural universities across South Africa and Nigeria agreed that they were well assessed every semester. This implies that assessment of students according to this finding of the study is relatively well carried out based on the opinion of student respondents in the selected universities in the two countries. This implies that students in the selected rural universities do not experience learning challenges following the type of assessment given to them by lecturers. This finding concurs with the work of Anzene [7] who states that quality assessment enhances quality learning. Hence, the finding of this study implies that assessment is not a major contributing factor to the learning challenges experienced by undergraduate university students in the selected rural universities in South Africa and Nigeria. Thus, learning challenges is expected to be reduced in these two countries following the report of students on the quality of assessment given to and received by them.

Table 2. Responses of students on assessment by lecturers

\begin{tabular}{|c|c|c|c|c|}
\hline \multirow{2}{*}{ Statement: I am well assessed by lecturers every semester } \\
\hline \multirow{2}{*}{ Response } & \multicolumn{2}{|c|}{$\begin{array}{c}\text { South African } \\
\text { Respondents }\end{array}$} & \multicolumn{2}{c|}{ Nigerian Respondents } \\
\cline { 2 - 5 } & Frequency & Percentage & Frequency & Percentage \\
\hline No & 93 & 19.0 & 55 & 12.4 \\
\hline Unsure & 154 & 31.4 & 130 & 29.3 \\
\hline Yes & 243 & 49.6 & 259 & 58.3 \\
\hline Total & 490 & 100 & 444 & 100 \\
\hline
\end{tabular}

Table 3. Responses of students on assessment types

\begin{tabular}{|c|c|c|c|c|}
\hline \multirow{4}{*}{ Response Statement: I like the way we are assessed } \\
\cline { 2 - 5 } & \multicolumn{2}{|c|}{$\begin{array}{c}\text { South African } \\
\text { Respondents }\end{array}$} & \multicolumn{2}{c|}{ Nigerian Respondents } \\
\cline { 2 - 5 } & Frequency & Percentage & Frequency & Percentage \\
\hline No & 55 & 11.2 & 55 & 12.4 \\
\hline Unsure & 214 & 43.7 & 130 & 29.3 \\
\hline Yes & 221 & 45.1 & 259 & 58.3 \\
\hline Total & 490 & 100 & 444 & 100 \\
\hline
\end{tabular}

Table 3 shows that while $11.2 \%$ of the respondents from the selected South African rural university disagreed to the statement that they like the way they were assessed, $43.7 \%$ were unsure and $45.1 \%$ agreed. Meanwhile, from the selected rural based Nigerian university, $12.4 \%$ of the respondents disagreed to the statement that they like the way they were assessed, $29.3 \%$ were unsure and $58.3 \%$ agreed. This finding shows that majority of the students from the selected rural universities in the two countries were satisfied with the type of assessment given by 
lecturers. Meanwhile, a review of the findings of the work of Fook, Sidhu [10] shows that assessment type can constitute major learning challenges for students if not well handled. Suffice to state that following this finding of the study, the type of assessment given by lecturers in the selected rural universities in the two countries is possibly well-handled, hence, does not cause major learning challenges for the students.

Table 4. Responses of students on usefulness of assessment given by lecturers

\begin{tabular}{|c|c|c|c|c|}
\hline \multicolumn{5}{|c|}{$\begin{array}{c}\text { Statement: The assessment given by lecturers has helped to make me } \\
\text { better }\end{array}$} \\
\hline \multirow[t]{2}{*}{ Response } & \multicolumn{2}{|c|}{$\begin{array}{c}\begin{array}{c}\text { South African } \\
\text { Respondents }\end{array} \\
\end{array}$} & \multicolumn{2}{|c|}{ Nigerian Respondents } \\
\hline & Frequency & Percentage & Frequency & Percentage \\
\hline No & 56 & 11.4 & 73 & 16.4 \\
\hline Unsure & 114 & 23.3 & 117 & 26.4 \\
\hline Yes & 320 & 65.3 & 254 & 57.2 \\
\hline Total & 490 & 100 & 444 & 100 \\
\hline
\end{tabular}

This finding from table 4 shows that majority of the respondents from the two selected rural universities in South Africa and Nigeria agreed that the assessments given to them by their lecturers are helpful and do not cause learning challenges for them. For instance, from table 4 , it is shown that while $11.4 \%$ of the students from the selected rural based South African university disagreed that the assessment given by lecturers has been helpful in making them better, $23.3 \%$ were unsure, and $65.3 \%$ agreed. Similarly, while $16.4 \%$ of the respondents from the selected Nigerian rural based university disagreed to the statement that the assessment given to them by lecturers has helped to make them better, $26.4 \%$ were unsure, and $57.2 \%$ agreed. This finding corroborates one of the findings of the work of Anzene [7] who states that assessment students are majorly focused and targeted at making them better. He further opines that the kind of assessments given to students is to be relevant and helpful to them, otherwise, the purpose for such would be defeated and learning challenges can be constituted and the learning abilities of such students can be negatively affected. Suffice to state that following this finding of the study, the assessments given to students by lecturers in the selected rural universities across South Africa and Nigeria are of relevance to the students.

Table 5. Responses of students on feedback received from lecturers in class

\begin{tabular}{|c|c|c|c|c|}
\hline \multicolumn{2}{|c|}{ Statement: I enjoy the type of feedback I get from lecturers in class } \\
\hline \multirow{2}{*}{ Response } & \multicolumn{2}{|c|}{$\begin{array}{c}\text { South African } \\
\text { Respondents }\end{array}$} & \multicolumn{2}{c|}{ Nigerian Respondents } \\
\cline { 2 - 5 } & Frequency & Percentage & Frequency & Percentage \\
\hline No & 148 & 30.2 & 116 & 26.1 \\
\hline Unsure & 230 & 46.9 & 181 & 40.8 \\
\hline Yes & 112 & 22.9 & 147 & 33.1 \\
\hline Total & 490 & 100 & 444 & 100 \\
\hline
\end{tabular}

The analysed data presented in table 5 show that the type of feedbacks received by students in class from lecturers in the selected rural universities across South Africa and Nigeria tends to be a learning challenge for students. This is because while many of the respondents were unsure if they enjoyed the type feedback given by lecturers in class, some disagreed, while few agreed. Hence, it can be deduced that the type of feedback received by students from lecturers in the selected rural universities causes learning challenges for the students. For instance, $30.2 \%$ of the respondents from the selected South African rural based university disagreed to the statement that they enjoy the type of feedback given to them by lecturers in class, $46.9 \%$ were unsure and $22.9 \%$ agreed. Similarly, $26.1 \%$ of the respondents from the selected Nigerian rural university disagreed to the statement that they do enjoy the type of feedback given to them by lecturers in class, $40.8 \%$ were unsure and $33.1 \%$ agreed. This finding coincides with the finding of the work of Daniels, McBride [6] who state that learning is incomplete without feedback from lecturer. They however further state that the feedbacks given to students by lecturers are to be properly done. This implies that when feedbacks are not properly done, they are capable of constituting learning challenges for students, thereby hampering their learning abilities. This finding is also supported by the social learning theorist who though encourages construction of knowledge by students, yet hold the view that the roles of lecturers are significant and cannot be overlooked or overemphasized. In congruence to this finding, Uleanya [15] opines that the position of lecturer in aiding students' learning abilities is paramount, hence, student-lecturer relationship is strongly encouraged, as such is expected to help boost the self-confidence of students while they get constructive feedbacks from their lecturers. Following the findings of the study, it can be stated that while majority of the students in the selected rural universities are pleased with the type of assessment given, they do not enjoy the type of feedback received from lecturers. Suffice to state that, the issue of feedbacks from lecturers in the selected South African and Nigerian rural based universities are to be critically looked into and adjusted to enable the students to become better academically.

Table 6. Responses of students on electronic feedback from lecturers

\begin{tabular}{|c|c|c|c|c|}
\hline \multirow{3}{*}{ Response } & \multicolumn{2}{|c|}{$\begin{array}{c}\text { South African } \\
\text { Respondents }\end{array}$} & \multicolumn{2}{c|}{ Nigerian Respondents } \\
\cline { 2 - 5 } & Frequency & Percentage & Frequency & Percentage \\
\hline No & 126 & 25.7 & 174 & 39.2 \\
\hline Unsure & 211 & 43.1 & 140 & 31.5 \\
\hline Yes & 153 & 31.2 & 130 & 29.3 \\
\hline Total & 490 & 100 & 444 & 100 \\
\hline
\end{tabular}

Feedbacks given to students vary. For instance, 
Reviews of the works of $[12,14]$ show that while feedbacks can be given using face to face contact, electronic gadgets can also be used for feedback. Hence, table 6 shows the responses of students regarding electronic feedback received from lecturers. $25.7 \%$ of the South African student respondents disagree that they (students) do not enjoy the feedback received from lecturers through email. $43.1 \%$ of the South African student respondents are unsure whether they (students) enjoy the feedback received from lecturers through email. However, $31.2 \%$ of the South African student respondents agree that they (students) enjoy the feedback received from lecturers through email. On the other hand, $39.2 \%$ of the Nigerian student respondents disagree that they (students) do not enjoy the feedback received from lecturers through email. $31.5 \%$ of the Nigerian student respondents are unsure whether they (students) enjoy the feedback received from lecturers through email. However, $29.3 \%$ of the Nigerian student respondents agree that they (students) enjoy the feedback received from lecturers through email. The result of the finding suggests poor electronic feedback from lecturers as one of the causes of learning challenges experienced by undergraduate university students in the selected countries. This corroborates the works of Tsai, Tsai, YiLin [11] as well as Jovanovic, Devedzic [12] who view feedback from lecturers as source of motivation for students. In addition, $[13,14]$ supports the use of ICT facilities in teaching and learning exercises. This includes assignments and feedbacks from lecturers. Hence, failure to maximize this avenue in the 21 st century education system may cause learning challenges for students. This implies that where lecturers in the selected rural institutions of learning fail to adopt electronic medium appropriately in giving feedback to students can constitute learning challenges for them. Moreover, in the $21^{\text {st }}$ century and with the advent of the happenings and practices in the education sector as well as others in the Fourth Industrial Revolution (4IR) era, use of electronic gadgets in various walks of life inclusive of education is inevitable. Suffice to state that the adoption and use of electronic gadgets as means of giving feedbacks to students are to be embraced by lecturers, regardless of where their institutions of learning are situated.

From the finding based on the analysed data presented in table 7, it can be inferred that responses from the two countries on each of the statements are significantly different since the P-value for all the statements in the Table are less than the significance level $(0.05)$ except that of statement 2 (the type of assessment given to students is commendable) in which the P-value $(0.585)$ is greater than 0.05 which implies that submissions from the selected rural based universities in South Africa and Nigeria on the statement are similar. Hence, it can be concluded that respondents' views on Assessment and Feedback from the two countries are statistically different, except on the type of assessment and feedback given to the students.

Table 7. Comparative Analysis of the Responses from the two countries on Assessment and Feedback

\begin{tabular}{|c|c|c|c|c|c|c|c|}
\hline SN & Statement & $\begin{array}{c}\text { Country } \\
\text { Sign } \\
\end{array}$ & $\mathbf{N}$ & Mean Rank & $\begin{array}{l}\text { Sum of } \\
\text { Ranks }\end{array}$ & Test Statistic & P-Value \\
\hline \multirow{3}{*}{1} & \multirow{3}{*}{$\begin{array}{l}\text { Students are well } \\
\text { assessed every semester }\end{array}$} & SA & 490 & 453.13 & 222035 & \multirow{3}{*}{101740} & \multirow{3}{*}{0.048} \\
\hline & & NG & 444 & 483.36 & 214610 & & \\
\hline & & Total & 934 & & & & \\
\hline \multirow{3}{*}{2} & \multirow{3}{*}{$\begin{array}{l}\text { The type of assessment } \\
\text { given to students is } \\
\text { commendable }\end{array}$} & SA & 490 & 463.30 & 227018 & \multirow{3}{*}{106723} & \multirow{3}{*}{0.585} \\
\hline & & NG & 444 & 472.13 & 209627 & & \\
\hline & & Total & 934 & & & & \\
\hline \multirow{3}{*}{3} & \multirow{3}{*}{$\begin{array}{l}\text { The assessment given by } \\
\text { lecturers helps to make } \\
\text { students better }\end{array}$} & SA & 490 & 497.31 & 243686 & \multirow{3}{*}{94172} & \multirow{3}{*}{$<0.0001$} \\
\hline & & NG & 444 & 464.60 & 192962 & & \\
\hline & & Total & 934 & & & & \\
\hline \multirow{3}{*}{4} & \multirow{3}{*}{$\begin{array}{c}\text { Students enjoy the type } \\
\text { of feedback they get from } \\
\text { lecturers }\end{array}$} & SA & 490 & 465.36 & 228025 & \multirow{3}{*}{107730} & \multirow{3}{*}{$<0.0001$} \\
\hline & & NG & 444 & 469.86 & 208620 & & \\
\hline & & Total & 934 & & & & \\
\hline \multirow{3}{*}{5} & \multirow{3}{*}{$\begin{array}{l}\text { Students enjoy feedback } \\
\text { received through email }\end{array}$} & SA & 490 & 491.71 & 240935.50 & \multirow{3}{*}{96919.50} & \multirow{3}{*}{0.002} \\
\hline & & NG & 444 & 440.79 & 195709.50 & & \\
\hline & & Total & 934 & & & & \\
\hline
\end{tabular}

Source: Analysis of Author's field work. ('SA' is used to represent South Africa, while 'NG' is used for Nigeria). 


\section{Conclusions and Recommendations}

The study explored undergraduates' perception on assessments and feedbacks using two selected rural based universities in South Africa and Nigeria. The study highlights that assessment and feedbacks are important aspects of teaching and learning activities in any learning environment, university inclusive. Assessment and feedbacks are equated to items in Schramm's Communication Model which are seen as continuous activities from sender (lecturers) to receivers (students), vis-à-vis from receivers (students) to senders (lecturers). In other words, assessment and feedbacks contribute immensely towards making communication in the teaching and learning environment complete. Sequel to the findings of this study and the Schramm's Communication Model, assessment and feedbacks may be presented as taking the position of " $\mathrm{M}$ " which represents "message in the model. "Thus, the model will be represented as shown below:

\section{Lecturers}

\section{$\mathbf{A} \boldsymbol{\&} \mathbf{F} \downarrow \uparrow \mathbf{R}$ Students}

Source: Coined by Researcher from Schramm's Communication Model

"A and F" in the model above stand for Assessment and Feedback which are to come from lecturers, while, "R" stands for "Response" which is to come from students.

Sequel to the findings of the study, the following recommendations are considered useful:

- More lecturers should be recruited and empowered through the provision of necessary facilities. This will aid them in the forms of assessment given to their students as well as the feedbacks.

- Students should be allowed to respond to feedbacks given to them by lecturers, especially where clarity is needed. This can be possible, when there is good lecturer-student relationship. Thus, good lecturer-student relationship should be promoted in universities and by extension other institutions of learning.

- All-encompassing periodic on the job trainings and workshops should be provided for lecturers. These trainings and workshops should be designed in such a manner that lecturers will be motivated and taught various ways on how to promote good lecturer-student relationship, improvise in creating different assessment and feedback strategies, acquire and utilize best practices across the globe on assessing and giving feedback to large classes.

Additionally, it is noteworthy to state that the study was limited to only two selected South African and Nigerian based rural universities. Meanwhile, assessment and feedbacks are important segments of teaching and learning activities in institutions of learning in both rural and urban centres. Hence, it is suggested that similar study should be conducted using more selected institutions of learning in both rural and urban centres as well. More countries within and outside the African continent can be explored in subsequent study.

\section{Acknowledgement}

The researcher will like to acknowledge and appreciate the department of Education Leadership and Management, faculty of education and research committee of the University of Johannesburg, Auckland Park, Gauteng, South Africa, for supporting this research in different ways.

\section{REFERENCES}

[1] J. Biggs. Teaching for Quality Learning at University. SRHE and Open University Press, Buckingham, UK, 1999.

[2] D. Boud. Enhancing Learning through Self-assessment. Kogan Page, London, 1995.

[3] Q.S. Memory, D. Memory. Corrupt Academic Practices: A Tragedy in Nigerian Educational System. Journal of Education and Practice, Vol.4, No. 27.

[4] J.S. Petters, M.O. Okon. Students' Perception of Causes and Effects of Examination Malpractice in the Nigerian Educational System: The Way Forward for Quality Education. Procedia - Social and Behavioural Sciences, Vol.114, No.1 125-129

[5] C. Samford, A. Shacklock, C. Connors, F. Galtung. Measuring Corruption. Routledge, New York, 2016.

[6] V.I. Daniels, A. McBride. Paraeducators as critical team members: Redefining roles and responsibilities. NASSP Bulletin, Vol.85, 623 .

[7] S. Anzene. Trends in Examination Malpractice in Nigerian Educational System and its Effects on the Socio-Economic and Political Development of Nigeria. Journal of Humanities and Social Sciences (AJHSS), Vol.2, No.3, 1-8

[8] R. Kumar. Research Methodology A Step-by-Step Guide for Beginners. SAGE Publications, London 2019.

[9] J.W. Creswell. Research Design: Qualitative, Quantitative and Mixed Methods Approaches (4th edn). Thousand Oaks, CA, Sage, London, 2014.

[10] C.Y. Fook, G.K. Sidhu. Investigating Learning Challenges Faced by Students in Higher Education. Procedia - Social and Behavioral Sciences, Vol.186, 604-612.

[11] F. Tsai, C. Tsai, K. YiLin. The evaluation of different gaming modes and feedback types on game-based formative assessment in an online learning environment. Computers \& Education, Vol.81, 259-269. 
[12] J. Jovanovic, V. Devedzic. Open Badges: Novel Means to Motivate, Scaffold and Recognize Learning. Technology, Knowledge and Learning, Vol.20, No.1, 115-122.

[13] G. Kirkup, A. Kirkwood. Information and communications technologies (ICT) in higher education teaching - a tale of gradualism rather than revolution. Learning, Media and Technology, Vol.30, No.2, 185-199.
[14] C. Uleanya, B.T. Gamede. Technology: Solution to Quality Rural University Education. International Journal of Interdisciplinary Educational Studies, Vol.13, No.2, 1-10.

[15] C. Uleanya. Exploring Effects of Lecturers-Students' Relationship on Students Academic Performances in Selected Rural Universities. Interchange, Vol.51, No.4, 345-360. 10.1007/s10780-019-09377-x. 